AKTUALITA, Vol. 3 No.1 2020 hal. 94-109

\title{
TANGGUNG JAWAB NOTARIS TERHADAP PENERAPAN KLAUSULA EKSONERASI DALAM PERJANJIAN KREDIT PEMILIKAN RUMAH
}

\author{
Muhamad Ruby Khadafy, Neni Sri Imaniyati \\ Alumni Program Studi Magister Kenotariatan, Dosen Ilmu Hukum Unisba \\ Pascasarjana Universitas Islam Bandung \\ Email: rubykhadafy@gmail.com \& imaniyati89@gmail.com
}

\begin{abstract}
Abstrak : Perkembangan ekonomi yang begitu pesat menjadikan seringnya penggunaan kontrak/perjanjian baku dikalangan pelaku bisnis seperti perjanjian kepemilikan rumah. Proses pemilikan rumah tersebut dilaksanakan melalui proses jual-beli. dimana pemerintah menyediakan dana dalam bentuk kredit yang disalurkan kepada bank, ditunjuk guna membiayai pemilikan perumahan secara kredit sebagai produk yang ditawarkan bank (KPR), diikat dalam sebuah perjanjian, dituangkan dalam suatu form. Pilihannya hanya menandatangani perjanjian yang cukup berat sebelah dengan konsekuensi take it or leave it. Belum lagi dengan adanya pencantuman klausula eksonerasi yang semakin meminimalkan atau bahkan menghapus tanggung jawab salah satu pihak. Tujuan penelitian untuk menganalisis tanggung jawab notaris terhadap penerapan klausula eksonerasi dalam perjanjian kredit pemilikan rumah. Penelitian ini menggunakan metode yuridis normatif. Data yang digunakan data sekunder. Teknik Pengambilan data melalui studi kepustakaan. Hasil dari penelitian diperoleh bahwa notaris kehadirannya dikehendaki oleh aturan hukum untuk membantu dan melayani masyarakat dalam pembuktian tertulis yang bersifat otentik mengenai keadaan, peristiwa atau perbuatan hukum dalam hal pemberi nasihat hukum maupun dalam proses perancangan sebuah perjanjian untuk mencegah dan mengurangi munculnya klausula eksonerasi yang dapat merugikan salah satu pihak, serta bertanggung jawab untuk menjamin kepastian hukum dan dapat menghindari terjadinya sengketa diantara para pihak yang terikat dalam sebuah ikatan suatu perjanjian atau kontrak.
\end{abstract}

Kata Kunci : Perjanjian, Eksonerasi, KPR, Tanggung jawab, Notaris

Abstract: Rapid economic development has often led to the frequent use of public contracts/agreements among business owners such as home loan agreement. The process of home loan is conducted through a sell-purchase process in which the government provides funds in the form of credit channeled to the bank, designated to finance the home loan on a credit basis as a product offered by the bank (KPR), tied up in an agreement, and covered in a form. The choice is simply to sign an unfair agreement with the consequence to take it or leave it. Additionally, the inclusion of exoneration clauses further minimizes or even eliminates the responsibility of one party. This study aimed at analyzing the notary's responsibility for the application of the exoneration clause in the home loan agreement. This study used a normative juridical method by using secondary data through library study as its data collection technique. The result showed that the existence of notary is required by legal rules to assist and serve the community in written evidence that is authentic about legal conditions, events, or actions in 
terms of providing legal advice or designing an agreement to prevent the process and reduce the emergence of exoneration clauses that can harm one party. Besides that, the notary is also responsible for guaranteeing legal certainty and able to avoid disputes between the parties that are bound in an agreement or contract.

Keywords: Agreement, Exoneration, KPR, Responsibility, Notary

\section{A. PENDAhUluan}

Dewasa ini, perkembangan laju pembangunan ekonomi Indonesia dirasakan begitu pesat. Hal ini terjadi demi terwujudnya pemenuhan kebutuhan dalam masyarakat. Perkembangan di bidang perekonomian yang semakin pesat membawa konsekuensi semakin seringnya penggunaan suatu kontrak/ perjanjian baku di kalangan para pelaku bisnis. Salah satu pemenuhan kubutuhan yang tejadi dimasyarakat dilakukan melalui kegiatan berbisnis. Salah bisnis jual beli perumahan atau yang lebih dikenal dengan real estate. Semakin berkembang dalam dunia bisnis dengan semakin banyaknya pengembang atau perusahaan dibidang perumahan memudahkan masyarakat untuk memilih pengembang atau pengusaha yang sesuai dengan kemampuan keuangannya masingmasing. Pertumbuhan penduduk yang cukup pesat di Indonesia menyebabkan besarnya kebutuhan ketahui bahwa tempat tinggal adalah suatu kebutuhan pokok bagi setiap manusia.

Proses dari pemilikan rumah tersebut didapatkan dari proses perjanjian jual beli sebagian besar perjanjian dalam dunia bisnis berbentuk perjanjian baku atau perjanjian standar. Perjanjian kredit dituangkan dalam bentuk perjanjian baku salah satu asasnya berlandaskan pada asas kebebasan berkontrak. Dalam hal tersebut pemerintah menyediakan dana dalam bentuk kredit yang disalurkan kepada bank yang ditunjuk guna membiayai pemilikan perumahan secara kredit sebagai suatu produk yang ditawarkan oleh bank. Kredit Pemilikan Rumah atau biasa disebut (KPR) tentunya menjadi prodak yang banyak diminati dikalangan masyarakat luas serta tidak asing lagi dengan beberapa syarat dan ketentuan yang diajukan oleh pihak Bank pemberi kredit. Sebut saja misalnya ketentuan tentang dapat berubahnya suku bunga kredit pada waktu yang tidak ditentukan terlebih dahulu. Pihak 
bank tak jarang kita mendapati ketentuan didalam brosur yang menyebutkan bahwa:

"Jika terjadi kredit macet, Bank berhak menjual asset atau jaminan (rumah) maksimal sebesar Hak Tanggungan senilai $125 \% "$

Pengurus Yayasan Lembaga Konsumen Indonesia (YLKI), Sudaryatmo, mengatakan beberapa ketentuan yang disodorkan pihak bank maupun developer kerap menjerat masyarakat selaku konsumen perumahan. Tak jarang para konsumen yang belakangan merasa 'tertipu' dengan ulah pengembang dan bank. lanjut Sudaryatmo, diketahui bahwa dalam UU No 8 Tahun 1999 tentang Perlindungan Konsumen telah mengatur secara tegas larangan terhadap pelaku usaha membuat iklan yang mengelabui konsumen. (www.hukumonline.com/berita/baca/lt4b3f4 93147a2a/waspadai-klausulabaku-dalamperjanjian-kredit-pemilikan-rumah/ diunduh pada tanggal 10 april 2020 pada pukul 14.30 WIB).

Dalam pelaksanaannya pemerintah telah menetapkan pedoman pengikatan jualbeli rumah melalui Keputusan Menteri Perumahan Rakyat (Menpera) No. DOI: https://doi.org/10.29313/aktualita.v0i0.5972
09/Kept/M/1995 yang menegaskan bahwa pengembang wajib melaksanakan pendirian bangunan sesuai waktu yang telah diperjanjikan menurut gambar arsitektur, denah, dan spesifikasi teknik bangunan yang menjadi bagian tak terpisahkan dalam perjanjian pengikatan jual-beli rumah tersebut.Hal ini tercantum pada UndangUndang Nomor 4 Tahun 1992 Tentang Perumahan dan Pemukiman selanjutnya disingkat UU Perumahan dan Pemukiman Pasal 4 huruf a yang menyatakan bahwa penataan perumahan dan pemukiman bertujuan untuk memenuhi kebutuhan rumah sebagai salah satu kebutuhan dasar manusia, dalam rangka peningkatan dan pemerataan kesejahteraan rakyat, dan penjelasan umum Undang-undang Permahan dan Pemukiman alinea kedua yang menyatakan bahwa perumahan dan pemukiman merupakan kebutuhan dasar manusia dan mempunyai peranan yang sangat strategis dalam pembentukan watak serta kepribadian bangsa, dan perlu dibina serta dikembangkan demi kelangsungan dan peningkatan kehidupan. Permukiman yang layak salah satu tujuan dari berkembangannya kelangsungan hidup manusia. Hal tersebut menjadikan pemilikan rumah sebagai suatu hal yang wajib dimiliki 
oleh manusia. Bank dalam hal ini menawarkan produk yang banyak diminati demi terwujudnya kebutuhan dasar manusia yaitu rumah. Hanya saja terdapat syaratsyarat yang harus dipenuhi serta di sepakati oleh para pihak. Dalam asas kebebasan berkontrak terkandung suatu pandangan bahwa orang bebas untuk melakukan atau tidak melakukan perjanjian, bebas dengan siapa ia mengadakan perjanjian, bebas tentang apa yang ingin diperjanjikan dan bebas untuk menetapkan syarat-syarat perjanjian, yang dimana hal ini pada akhirnya akan menimbulkan ketidakadilan bagi debitur.

"On the other hand, there is the potential for inefficient, and even unjust, terms to be accepted by signatories to these contracts. Such terms might be seen as unjust if they allow the seller to avoid all liability or unilaterally modify terms or terminate the contract." (Patterson, E., The Delivery of a Life-Insurance Policy, 33 Harvard Law Review, 198 diunduh secara online pada tanggal 10 april 2020 pada pukul 14.58 WIB).

Adalah adanya kesepakatan antara para pihak yang membuatnya seperti ditentukan dalam Pasal 1320 Kitab Undang-Undang DOI: https://doi.org/10.29313/aktualita.v0i0.5972
Hukum Perdata. Syarat sahnya perjanjian riil adalah telah dilaksanakan perbuatan tertentu, misalnya pada perjanjian penitipan barang seperti ditentukan dalam Pasal 1697 Kitab Undang-Undang Hukum Perdata. Syarat sahnya perjanjian formil adalah telah dipenuhinya suatu formalitas tertentu, misalnya pada hibah seperti ditentukan dalam Pasal 1682 Kitab Undang-Undang Hukum Perdata. (Kartini Muljadi, Gunawan Widjaja, 2004 : 134-135).

Adapun ciri dari perjanjian baku yaitu:

1. Isinya ditetapkan secara sepihak oleh kreditur yang posisinya relatif lebih kuat dari debitur.

2. Debitur sama sekali tidak ikut menentukan isi perjanjian tersebut

3. Terdorong oleh kebutuhan,debitur terpaksa menerima perjanjian tersebut

4. Bentuknya tertulis. (Abdul Kadir Muhammad, 2002 : 6).

Ciri-ciri tersebut dapat mencerminkan prinsip ekonomi dan kepastian hukum. Melihat prinsip ekonomi dan kepastian hukum dalam perjanjian baku dilihat dari kepentingan pengusaha bukan dari kepentingan konsumen. Dengan pembakuan syarat-syarat perjanjian, maka 
kepentingan ekonomi pengusaha lebih terjamin karena konsumen hanya menyetujui syarat-syarat yang ditawarkan oleh pengusaha disatu sisi karena membutuhkan demi kelangsungan hidupnya pribadi, keluarganya, ataupun lapangan usahanya. Dalam perjanjian baku biasanya dituangkan dalam suatu form pilihannya hanya menandatangani perjanjian yang cukup berat sebelah itu dengan konsekuensi take it or leave it. Belum lagi dengan adanya klausula eksonerasi yang semakin meminimalkan atau bahkan menghapus tanggung jawab dari salah satu pihak. (Munir Fuadi, 2002 : 228). Fenomena seperti ini menunjukkan bagaimana rendahnya posisi tawar bagi debitur bila berhadapan dengan bank dalam sebuah perjanjian kredit. Apalagi apabila debitur adalah kalangan masyarakat berekonomi lemah dimana dalam tataran praktis, untuk memperoleh kredit bank jauh lebih sulit dan melewati birokrasi yang panjang dibandingkan para pelaku ekonomi menengah ke atas. Hal tersebut dalam Praktik perjanjian baku sering dibuat dalam kondisi yang tidak berimbang. Produsen (Pelaku Usaha) memanipulasi perjanjian yang dibuat dalam ketentuan klausula baku. Biasanya perjanjian tersebut lebih menguntungkan salah satu pihak yaitu DOI: https://doi.org/10.29313/aktualita.v0i0.5972 pelaku usaha. (Abdul Hakim Barkatullah, 2010 : 53). Selain itu, pihak pengembang properti juga tidak jarang mencantumkan klausula baku dalam perjanjian jual beli perumahan. Klausula baku dalam bidang perumahan misalnya terdapat dalam perjanjian jual beli perumahan dalam klausula down payment (dp) atau booking fee yang menyebutkan bahwa:

"Seluruh uang yang telah dibayarkan oleh pihak kedua kepada pihak kesatu menjadi hangus dan tidak dapat dituntut kembali”.

Rendahnya kesadaran dan pengetahuan konsumen, tidak mustahil dijadikan lahan bagi pelaku usaha dalam transaksi yang tidak mempunyai itikad baik dalam menjalankan usaha, yaitu berprinsip untuk mencari keuntungan yang sebesarbesarnya dengan memanfaatkan minimnya pengetahuan konsumen. Konsumen memiliki risiko yang lebih besar daripada pelaku usaha, dengankata lain hak-hak konsumen sangat rentan. (Edmon Makarim, 2003 : 242).

Disebabkan posisi tawar konsumen yang lemah, maka hak-hak konsumen sangat riskan untuk dilanggar posisi tersebut perlu dilindungi oleh hukum dimana tujuan dari 
hukum itu sendiri untuk memberikan perlindungan dan mengayomi masyarakat. (Shidarta, 2004 : 112). Notaris merupakan pejabat umum yang memberikan pelayanan hukum terhadap masyarakat khususnya dalam membuat akta autentik serta memiliki kewenangan lainnya sebagaimana dimaksud dalam Undang-Undang Jabatan Notaris. Notaris adalah pejabat umum yang berwenang untuk membuat akta otentik dan kewenangan lainnya sebagaimana yang dimaksud dalam Pasal 1 ayat (1) UndangUndang Nomor 2 Tahun 2014 Tentang Perubahan Atas Undang-Undang Nomor 30 Tahun 2004 Tentang Jabatan Notaris. Berdasarkan ketentuan tersebut maka Notaris yang memiliki tugas membuat akta otentik harus dapat memahami ketentuan yang diatur oleh undang-undang agar masyarakat umum yang tidak mengetahui atau memahami aturan hukum dapat memahami dengan benar serta tidak melakukan hal-hal yang bertentangan dengan hukum. (Komar Andasasmita, 1983 : 2).

Notaris harus bertanggung jawab atas akta tersebut, bahwa akta tersebut adalah benar dan tidak akan menimbulkan gugatan atau tuntutan hukum di kemudian hari, dan jika terjadi gugatan atau tuntutan hukum akta tersebut merupakan alat pembuktian yang sempurna di persidangan. Jika akta yang dibuat notaris salah (tidak sempurna) maka dapat berakibat mengalami degradasi kekuatan pembuktian akta tersebut menjadi tidak autentik dan hanya mempunyai kekuatan selayaknya akta atau surat di bawah tangan. (Artikel-ImplikasiKlausula-Eksonerasi-Terhadap-AktaNotaris-23-Agustus-2018 diunduh pada tanggal 10 april 2020 pada pukul 16.15 WIB). Sehubungan dengan perlindungan terhadap konsumen, yang perlu mendapat perhatian utama dalam perjanjian baku adalah mengenai klausula eksonerasi Yaitu klausula yang berisi pembebasan atau pembatasan pertanggungjawaban dari pihak pelaku usaha yang lazimnya terdapat dalam jenis perjanjian tersebut. Menjadikan notaris dikenai tanggung jawab atas materi akta pasal 16 ayat 1 huruf a menyatakan :

"Notaris dalam menjalankan tugas berkewajiban bertindak jujur, seksama, mandiri, tidak memihak dan menjaga kepentingan pihak terkait dalam melakukan suatu perbuatan hukum" 
Dalam menentukan pengikatan perjanjian tersebut didasarkan oleh asas kebebasan berkontrak akan tetapi pada kenyataannya asas tersebut sering disalahgunakan (Peter M. Marzuki, BatasBatas Kebebasan Berkontrak, Yuridika. Vol. 18, No. 3, Mei 2003 : 203). Sebagaimana diketahui bahwa tidak ada satu ketentuanpun yang mengatur tentang klausula eksonerasi dalam BW Indonesia. Hukum kontrak kita yang bersumber dari BW Indonesia hanya mengatur batasan-batasan kontrak yang sifatnya masih umum.

Melalui tulisan ini akan dicoba untuk melakukan pengkajian tanggung jawab notaris terhadap keberadaan klausula eksonerasi dalam hal Kredit Pemilikan Rumah agar penggunaannya tidak secara serta merta merugikan para pihak yang mengikatkan dirinya pada suatu pengikatan perjanjian kontrak baku. Serta pembatasan terhadap penggunaan klausula eksonerasi juga untuk memahami pembatasan tentang asas kebebasan berkontrak yang dimuat dalam hukum kontrak, sehingga peran serta tanggung jawab notaris dalam menjalankan tugas serta tanggung jawabnya dalam hal sebagai penasehat hukum menciptakan keseimbangan para kontraktan lebih terjamin.

\section{B. PEMBAHASAN}

Keberadaan klausula eksonerasi adalah bertujuan membebaskan atau membatasi tanggung jawab salah satu pihak terhadap gugatan pihak lainnya dalam hal yang bersangkutan tidak atau tidak dengan semestinya melaksanakan kewajibannya yang ditentukan di dalam perjanjian tersebut. (Sutan Remy Sjahdeni, 1993 : 75). Klausul tersebut meyebabkan hubungan hukum antar para pihak seringkali melemahkan posisi debitur karena secara sepihak kreditur sudah menyiapkan satu kondisi perjanjian dengan adanya perjanjian baku, yang syarat-syaratnya secara sepihak ditentukan pula oleh pihak kreditur. (Celina Tri Siwi Kristiyanti, 2014 : 12). Suatu klausula eksonerasi dapat membawa akibat, bahwa hak dan kewajiban dari para pihak menjadi jauh tidak berimbang. Mariam Darus Badrulzaman menyebut klausula eksonerasi sebagai klausula yang berisi pembatasan pertanggungjawaban kreditur. (Mariam Darus Badrulzaman, 1981 : 95).

Munculnya klausula eksonerasi dapat disebabkan oleh beberapa hal antara 
lain kecermatan dalam berkontrak, itikad baik dalam berkontrak dan posisi tawar yang tidak seimbang. Sebab pertama yaitu kecermatan berkontrak berkaitan dengan wawasan hukum pihak-pihak pembentuk kontrak. (Ida Bagus Wyasa Putra, 2000 : 64). Oleh karena itu fungsi dari asas itikad baik harus diterapkan dalam berbagai tahapan, yang dimulai dari pra kontrak, pembuatan kontrak dan pelaksanaan kontrak dalam rangka untuk menjamin kejujuran dan keadilan kontraktual. Perjanjian baku yang memuat klausula eksonerasi yaitu klausula yang meniadakan atau membatasi kewajiban salah satu pihak (kreditur) untuk membayar ganti rugi kepada debitur, memiliki ciri-ciri sebagai berikut yaitu (Mariam Darus Badrulzaman, 1994 : 50).

Isinya ditetapkan sepihak oleh kreditur yang posisinya relatif lebih kuat dibandingkan debitur, Debitur sama sekali tidak ikut menentukan isi perjanjian itu, Terdorong oleh kebutuhannya, debitur terpaksa menerima perjanjian tersebut, Bentuknya tertulis, Dipersiapkan secara massal atau kolektif. Menurut Ahmad Miru perjanjian baku adalah perjanjian yang mengikat para pihak yang menandatanganinya, walaupun harus diakui

DOI: https://doi.org/10.29313/aktualita.v0i0.5972 bahwa klausula yang terdapat dalam perjanjian baku banyak mengalihkan beban tanggung gugat dari pihak perancang perjanjian baku kepada pihak lawannya, namun setiap kerugian yang timbul dikemudian hari akan tetap ditanggung oleh para pihak yang harus bertanggung gugat berdasarkan klausula perjanjian tersebut, kecuali jika klausula tersebut merupakan klausula yang dilarang berdasarkan Pasal 18 Undang-undang Nomor 8 Tahun 1999 tentang Perlindungan Konsumen. (Ahmad Miru , Sutarman Yudo, 2004 :118). Pada prinsipnya Undang-Undang Perlindungan Konsumen tidak melarang pelaku usaha sepertihalnya Bank untuk membuat perjanjian yang memuat klausula baku atas setiap dokumen dan perjanjian transaksi usaha perdagangan barang atau jasa sepanjang perjanjian baku atau klausula baku tersebut tidak mencantumkan ketentuan sebagaimana dilarang dalam pasal 18 ayat (2) Undang-Undang tentang Perlindungan Konsumen tersebut. Namun perlu kita ketahui bahwa yang menjadi permasalahan dalam perjanjian baku adalah bukan pada perjanjian baku, malainkan terdapatnya perjanjian baku atau standard contract yang bersifat eksonerasi (klausula eksonerasi) yang sering tercantum dalam 
prodak bank seperti kredit Kepemilikan Rumah (KPR). Perjanjian eksonerasi dapat membebaskan tanggungjawab seseorang pada akibat hukum yang terjadi karena kurangnya pelaksanaan kewajibankewajiban yang diharuskan oleh perundangundangan, antara lain tentang masalah ganti rugi dalam hal perbuatan ingkar-janji. Untuk itu demi mengurangi keberadaan eksonerasi yang senantiasa merugikan pihak yang lemah dibutuhkan peranan negara melalui Pejabat Notaris agar pelaksanaan asas kebebasan berkontrak tidak bertentangan dengan makna diciptakannya asas itu dan agar etika menjadi landasan pelaksanaan asas itu. (Peter M. Marzuki, Op. Cit : 203).

Kata kredit berasal dari bahasa latin creditus yang merupakan bentuk past participle dari kata credere yang berarti to trustatau faith. Kata trust itu sendiri berarti kepercayaan. Dapat dikatakan dalam hubungan ini bahwa kreditur dalam hubungan perkreditan dengan debitur mempunyai kepercayaan bahwa debitur dalam waktu dan dengan syarat-syarat yang telah disetujui bersama, dan dapat mengembalikan kredit yang bersangkutan. (Rudyanti Dorotea Tobing, 2010 : 178). Pemberian kredit merupakan kegiatan utama

DOI: https://doi.org/10.29313/aktualita.v0i0.5972 yang dilakukan oleh bank mengandung risiko yang dapat berpengaruh pada kesehatan dan kelangsungan usaha bank sepertihal nya kredit pemilikan rumah. Namun mengingat sebagai lembaga intermediasi, sebagian besar dana bank berasal dari dana masyarakat, maka pemberian kredit perbankan banyak dibatasi oleh ketentuan undang-undang dan bank Indonesia. Mengingat modal yang dimiliki perorangan biasanya tidak mampu mencukupi dalam mendukung peningkatan kehidupan yang layak sepertihalnya memiliki rumah atau pun kebutuhan lainnya sehingga bantuan permodalan atau keuangan dari pihak kreditur sangat membantu untuk memenuhi kebutuhan di masyarakat. (Mohammad Wisno Hamin, "Perlindungan Hukum Bagi Nasabah (Debitur) Bank sebagai Konsumen Pengguna Jasa Bank Terhadap Risiko dalam Perjanjian Kredit Bank", Jurnal Lex Crimen,Vol. VI/No.1/Jan-Feb/2017). Berdasarkan pada Pasal 1338 Kitab Undang-Undang Hukum Perdata yang memuat asas kebebasan berkontrak. Di dalam praktik perbankan, setiap bank telah menyediakan blanko atau formulir perjanjian kredit yang isinya telah disiapkan terlebih dahulu. Blanko perjanjian kredit ini diserahkan terhadap debitur untuk 
disetujui dan tanpa memberikan kebebasan sama sekali kepada pihak lain untuk melakukan negosisasi atas syarat-syarat yang dihadapkan kepadanya. Pelaku usaha mengatur hak-haknya yang menguntungkan, tetapi tidak kewajibannya, oleh karena praktik-praktik demikian perlu ditertibkan. (N.H.T. Siahaan, 2005 : 117). Hal ini perlu diperhatikan secara terperinci karena Posisi pihak pelaku usaha seperti hal nya Bank jauh lebih kuat ketimbang para konsumen yang merupakan perorangan, karena penguasaan informasi tentang produk sepenuhnya ada pada produsen (Nining Muktamar et al., 2005 : 2). Maka perlu adanya perlindungan hukum didalam nya Perlindungan hukum bagi rakyat meliputi dua hal, yakni:

a. Perlindungan hukum preventif, yakni bentuk perlindungan hukum dimana kepada rakyat diberikan kesempatan untuk mengajukan keberatan atau pendapat sebelum suatu keputusan pemerintah mendapatbentuk yang definitif;

b. Perlindungan hukum represif, yakni bentuk perlindungan hukum dimana lebih ditujukan dalam penyelesaian sengketa. (Sudikno Mertokusumo, 2009 : 41).

Tercantum dalam pasal 15 ayat (1) Undang-Undang Republik Indonesia Nomor 2 Tahun2014 Tentang Perubahan Atas Undang-Undang Nomor 30 Tahun 2004 Tentang jabatan Notaris disebutkan bahwa Notaris berwenang membuat Akta autentik mengenai semua perbuatan, perjanjian, dan penetapan yang diharuskan oleh peraturan perundang-undangan dan/atau yang dikehendaki oleh yang berkepentingan untuk dinyatakan dalam Akta autentik, menjamin kepastian tanggal pembuatan Akta, menyimpan Akta, memberikan grosse, salinan dan kutipan Akta, semuanya itu sepanjang pembuatan Akta itu tidak juga ditugaskan atau dikecualikan kepada pejabat lain atau orang lain yang ditetapkan oleh undang-undang. Notaris memiliki kewenangan dan kewajiban yang lain yang karena jabatannya diharuskan berperan lebih luas, karena mereka memiliki tanggung jawab yang luas baik secara administrasi, perdata bahkan juga secara pidana. Menurut UURI No. 30 Tahun 2004 sebagaimana diubah dengan UURI No. 2 Tahun 2014, dalam hal kewenangan yang dimilikinya bahwa notaris berwenang memberikan 
penyuluhan hukum sehubungan dengan pembuatan akta (Pasal 15 Ayat 2 huruf e). Ketentuan tersebut hendaknya dikaitkan dengan Pasal 16 Ayat (1) huruf a, yang menentukan bahwa notaris dalam menjalankan jabatannya wajib bertindak amanah, jujur, seksama, mandiri, tidak berpihak dan menjaga kepentingan pihakpihak yang terkait perbuatan hukum. (Made, November 2016. "pembatasan klausula eksonerasi" Jurnal Notariil, VOL. 1, No. 1, November 2016, 109http://ejournal.warmadewa.ac.id/index.php/j n pada tanggal 5 april 2020 pada pukul 14.20 WIB).

Perihal jual beli rumah masyarakat sering dihadapkan pada perjanjian pendahuluan yang berisikan perjanjian pengikatan jual beli antara Bank terhadap konsumen sebelum terjadi perjanjian jual beli rumah yang sesungguhnya. Hal tersebut biasanya berupa formular telah disiapkan terlebih dahulu oleh pelaku usaha dalam bentuk perjanjian baku. Diketahui bahwa seluruh isi perjanjian pengikatan jual beli tersebut ditentukan sepihak oleh pelaku usaha yang posisinya lebih kuat dibandingkan konsumen. Penggunaan perjanjian baku tersebut menimbulkan kerugian bagi konsumen pembeli rumah karena ternyata pengaturan hak dan kewajiban dalam perjanjian baku tersebut tidak seimbang dan cenderung menguntungkan pelaku usaha yang hal tersebut berdampak pada perjanjian kredit pemilikan rumah (KPR). Hal yang perlu di khawatirkan dengan kehadiran perjanjian standar, tidak lain karena dicantumkannya klausul eksonerasi (exemption clause) dalam perjanjian tersebut. Klausul yang mengandung kondisi membatasi ataubahkan menghapus sama sekali tanggung jawab yang semestinya dibebankan kepada pihak produsen/penyalur produk (penjual). (Nizla Rohaya, Maret 2018." pelarangan penggunaan klausula baku yang mengandung klausuka eksonerasi dalam perlindungan konsumen" Jurnal Hukum, VOL.6, no.1, Maret 2018, http://jurnal.umt.ac.id/index.php/replik/articl e/viewFile/1116/731 pada tanggal 5 april 2020 pada pukul 15.00 WIB).

Kenyataanya dalam substansi isi perjanjian pengikatan jual beli rumah terdapat pencantuman klausula eksonerasi. Dalam kenyataannya hal tersebut banyak terjadi tetapi sulit untuk dapat diterapkan sanksinya, tentunya berat sebelah bagi konsumen yang kedudukannya lemah untuk 
membuktikan tidak adanya kesepakatan dalam dibuatnya perjanjian pengikatan jual beli rumah. Pencantuman klausula eksonerasi dalam perjanjian pengikatan jual beli rumah yang substansinya berisikan pelaku usaha mengalihkan tanggung jawab, pelaku usaha melakukan dengan tindakan sepihak dan penolakan pengembalian uang ataupun menaikan suku bunga, serta melelang asset hak tanggungan sampai dengan 125\% kepada konsumen yang memberatkan dan merugikan konsumen. Berdasarkan ketentuan pasal $1320 \mathrm{KUH}$ Perdata dalam unsur sepakat belum terpenuhi, sebab konsumen tidak mempunyai kekuatan tawar-menawar dalam menentukan isi perjanjian pengikatan jual beli rumah dengan pelaku usaha. (Evi, (2013) Klausula Eksonerasi dalam Perjanjian Pengikatan Jual Beli yang Berdampak terhadap Kredit Pemilikan Rumah (KPR). http://repository.ub.ac.id/156476/ pada tanggal 5 april 2020 pada pukul 15.32 WIB).

Bentuk perlindungan konsumen dalam Perjanjian pengikatan jual beli yang berdampak pada perjanjian kredit pemilikan rumah yang isinya mengandung klausula eksonerasi ditandai dengan adanya pengalihan tanggung jawab pengembang, pelaku usaha melakukan tindakan sepihak dan penolakan pengembalian uang kepada konsumen sehingga dampak dari perjanjian yang dari awal telah dibuat tidak seimbang mengikuti dalam Perjanjian Kredit Pemilikan Rumah (KPR) menjadi kedudukan kreditur dan debitur menjadi tidak setara dengan pencantuman klausula eksonerasi dalam perjanjian tersebut. Notaris sebagai pengemban hukum diharapkan dapat memberikan pendapat hukum serta nasihat kepada para pihak sepertihal nya dalam sebuah perjanjian kredit pemilikan rumah dimana perlunya memberikan penyuluhan hukum dengan baik sepertihal nya tercantum dalam pasal 15 ayat 2 angka, maka hal tersebut dapat pula memperkecil peluang seorang notaris untuk dapat digugat secara perdata di Pengadilan. Notaris dapat digugat untuk memberikan ganti kerugian atas dasar perbuatan melawan hukum, karena notaris tidak melakukan kewajibannya yang telah ditentukan oleh Undang-Undang Jabatan Notaris serta terdapat pihak yang merasa dirugikan haknya yang sebelumnya tidak diberikan penjelasan apapun oleh notaris. Termasuk dalam suatu penerapan kontrak yang ternyta terdapat klausula eksonerasi 
yang sangat rentan terhadap penyalahgunaan keadaan terhadap pihak yang posisinya lemah. Oleh karena itu, peranan notaris dapat memberikan nasihat serta petunjuk dalam melakukan pelayanan secara adil, berimbang. Sehingga tanggung jawabnya harus dilandasi oleh integritas dan moral yang baik, sebagaimana keterampilan teoritis dan teknis dibidang profesi Notaris harus didukung oleh tanggung jawab dan etika profesi. Untuk itulah disarankan bagi notaris untuk memberikan informasi hukum yang penting yang selayaknya diketahui klien sepanjang yang berurusan dengan masalah hukum.

\section{PENUTUP}

Kredit pemilikan rumah merupakan prodak yang ditawarkan oleh bank yang hingga saat ini masih diminati oleh masyarakat sebagai solusi dalam pemenuhan kebutuhan demi kelangsungan hidup nya namun dalam kenyataannya dalam sebuah perjanjian kredit pemilikan rumah (KPR) terdapat Keberadaan klausula eksonerasi dalam perjanjian tersebut. Klausula eksonerasi adalah syarat yang secara khusus membebaskan pengusaha dari tanggung jawab terhadap akibat yang merugikan, yang timbul dari pelaksanaan perjanjian. Klausula eksonerasi dapat diartikan dari rumusan pengusaha secara sepihak, dapat juga berasal dari rumusan pasal undang-undang. Klausula eksonerasi rumusan pengusaha membebankan pembuktian pada konsumen, bahwa konsumen tidak bersalah dan inilah yang menyulitkan konsumen. Mengenai larangan pencantuman klausula baku tersebut diatur dalam pasal 18 Undangundang perlindungan konsumen. Jika dilihat dari sisi Pasal 1320 KUH Perdata dapat ditarik benang merah bahwa klausula baku pada perjanjian seperti halnya suatu perjanjian perjanjian kredit pemilikan rumah (KPR) pada umumnya harus memenuhi baik syarat-syarat objektif maupun syarat-syarat subjektif dari sahnya suatu perjanjian serta memenuhi asas kebebasan berkontrak, asas konsensualisme serta kedudukan yang seimbang dari para pihak yang membuat perjanjian. Serta menjungjung pada asas kebebasan berkontrak hanya saja terdapat batasan yang dalam penerapan sebuah klausula eksonenarasi yang dapat melemahkan salah satu pihak sehingga disinalah peran Jabatan Notaris kehadirannya dikehendaki oleh aturan hukum dengan maksud untuk membantu dan melayani masyarakat yang membutuhkan alat bukti tertulis yang bersifat otentik 
mengenai keadaan, peristiwa atau perbuatan hukum dalam hal pemberi nasihat hukum maupun dalam proses perancangan sebuah perjanjian untuk mencegah dan mengurangi munculnya klausula eksonerasi yang dapat merugikan salah satu pihak. Notaris bertanggung jawab untuk menjaminkepastian hukum dan sekaligus diharapkan pula dapat dihindari terjadinya sengketa diantara para pihak yang terikat dalam sebuah ikatan suatu perjanjian atau kontrak, bahwa pertanggungjawaban yang dilakukan oleh Notaris merupakan akibat lebih lanjut dari pelaksanaan Notaris dalam menjalankan tugas dan jabatannya, yang merupakan hak dan kewajiban yang diberikan peraturan perundang-undangan dalam melaksanakan tugasnya. Sehingga tanggung jawab yang digunakan dalam UUJN adalah tanggung jawab berdasarkan kesalahannya, atas pelanggaran yang dilakukannya karena sengaja melakukan perbuatan tersebut dan menimbulkan kerugian bagi para pihak tentu hal tersebut suatu hal yang harus dihindari sehingga dalam kasus penerapan klausula eksonerasi dalam sebuah kontrak yang dibuat oleh salah satu pihak seperti hal nya form dalam kredit pemilikan rumah notaris sebagai pemberi nasihat hukum wajib memberitahukan atau DOI: https://doi.org/10.29313/aktualita.v0i0.5972 menjelaskan sebab serta akibat yang terjadi jika dalam sebuah kontrak tersebut terdapat sebuah klausula eksonerasi berdasarkan Undang-undang Jabatan Notaris Pasal 16 Ayat (1) huruf a, yang menentukan bahwa notaris dalam menjalankan jabatannya wajib bertindak amanah, jujur, seksama, mandiri, tidak berpihak dan menjaga kepentingan pihak-pihak yang terkait perbuatan hukum.

Tidak hanya sebagai pemberi nasihat hukum tentu dalam persoalan perancangan sebuah kontrak Notaris dalam menjalankan jabatannya harus bekerjadengan hati-hati agar tidak terkena permasalahan suatu saat nanti terhadap akta yang pernah dibuat. Undang-undang Jabatan Notaris No. 30 Tahun 2004 Jo Undang-Undang Jabatan Notaris No. 2 Tahun 2014 tidak menegaskan secara eksplisif tentang batas waktu dari pertanggung jawaban Notaris atas akta yang telah dibuatnya. Sehingga meskipun seorang noaris sudah berakhir masa jabatannya maka tetap dapat digugat ke pengadilan dengan gugatan biaya ganti rugi berikut bunga oleh para pihak yang pernah membuat akta kepadanya atas kerugian yang ditimbulkan oleh Notaris tersebut sehingga mengakibatkan akta tersebut cacat hukum sebagai akta otentik. 


\section{DAFTAR PUSTAKA}

\section{A. Buku}

Abdul Hakim Barkatullah, Hak-Hak Konsumen, (Bandung: Nusa Media,2010)

Abdul Kadir Muhammad ,2002, Hukum Perjanjian, Alumni Bandung, Bandung.

Ahmad Miru dan Sutarman Yudo, Hukum

Perlindungan Konsumen, (Jakarta, PT. Raja Grafindo Persada, 2004)

Celina Tri Siwi Kristiyanti, HukumPerlindungan Konsumen, Cet. 4, (Jakarta, sinar grafika, 2014)

Edmon Makarim, Kompilasi Hukum Telematika(Jakarta: PT. Raja Grafindo Persada, 2003)

Ida Bagus Wyasa Putra, Aspek-Aspek Hukum Perdata Internasional Dalam Transaksi Bisnis Internasional, (Bandung,Refika Aditama, 2000)

Kartini Muljadi \& Gunawan Widjaja, Perikatan Pada Umumnya (Jakarta : PT. Raja Grafindo Persada, 2004)

Komar Andasasmita, Notaris Selayang Pandang, Cet. 2, (Bandung, 1983)
Mariam Darus Badrulzaman, Aneka Hukum Bisnis, (Bandung, PT. Alumni,1994)

Mariam Darus Badrulzaman, Perjanjian Baku (Standard) Perkembangannya di Indonesia, dalam Beberapa Guru Besar Berbicara tentang Hukum dan Pendidikan Hukum(Kumpulan Pidato Pengukuhan), (Bandung, Alumni, 1981)

Munir Fuadi, Pengantar Hukum Bisnis, Menata Bisnis Modern di Era Globalisasi, (Bandung: Citra Aditya Bakti, 2002)

N.H.T. Siahaan, Hukum Konsumen, Perlindungan Konsumen dan Tanggungjawab produk, (Jakarta: Panta Rei, 2005)

Nining Muktamar et al., Berperkara Secara Mudah, Murah dan Cepat, Pengenalan Mekanisme Alternatif Penyelesaian Sengketa Konsumen .( Jakarta:Piramedia, 2005)

Peter M. Marzuki, Batas-Batas Kebebasan Berkontrak, Yuridika. Vol. 18, No. 3, Mei 2003

Rudyanti Dorotea Tobing, hukum perjanjian kredit,laksbang publishing 2010 
Ryanto Pareno, Hak-Hak Khusus Notaris Sebagai Pejabat Publik Dalam Undang-Undang Jabatan Notaris,( Bandung, Eresco, 2006)

Shidarta, Hukum Perlindungan Konsumen Indonesia, Edisi Revisi (Jakarta: Grasindo,2004)

Sudikno Mertokusumo, Penemuan Hukum, (Bandung, Citra Aditya Bakti, 2009)

Sutan Remy Sjahdeni, Kebebasan Berkontrak dan Perlindungan Yang Seimbang Bagi Para Pihak Dalam Per-janjian Kredit Bank Di Indonesia, Institut Bankir Indonesia, (Jakarta 1993)

\section{B. Jurnal}

Evi, (2013) Klausula Eksonerasi dalam Perjanjian Pengikatan Jual Beli yang Berdampak terhadap Kredit Pemilikan Rumah (KPR). Available Online, http://repository.ub.ac.id/156476/

Made, November 2016. "pembatasan klausula eksonerasi” Jurnal Notariil, VOL. 1, No. 1, November 2016, 109-127Available Online at http://ejournal.warmadewa.ac.id/in dex.php/jn
Mohammad Wisno Hamin, "Perlindungan Hukum Bagi Nasabah (Debitur) Bank sebagai Konsumen Pengguna Jasa Bank Terhadap Risiko dalam Perjanjian Kredit Bank", Jurnal Lex Crimen,Vol. VI/No.1/Jan-Feb/2017

Nizla Rohaya, Maret 2018." pelarangan penggunaan klausula baku yang mengandung klausuka eksonerasi dalam perlindungan konsumen" Jurnal Hukum, VOL.6, no.1, Maret 2018, Available Online athttp://jurnal.umt.ac.id/index.php/r eplik/article/viewFile/1116/731

Patterson, E., The Delivery of a LifeInsurance Policy, 33 Law Review, 198

\section{Peraturan Perundang- Undangan}

Kitab Undang-Undang Hukum Perdata

Undang-Undang Nomor 4 Tahun 1992

Tentang Perumahan dan Pemukiman

Undang-Undang No 8 Tahun 1999 Tentang

Perlindungan Konsumen

Undang-Undang Nomor 2 Tahun 2014

Tentang Jabatan Notaris

Keputusan Menteri Perumahan Rakyat (Menpera) No. 09/Kept/M/1995

\section{Internert}


Muhamad Ruby Khadafy, Neni Sri Imaniyati, Tanggung Jawab Notaris Terhadap Penerapan Klausula...

Artikel-Implikasi-Klausula-Eksonerasi-

Terhadap-Akta-Notaris-23-Agustus-2018

www.hukumonline.com 